\title{
Security force assistance advisory team - inputs and outcomes
}

\section{Poradenský tím asistencie bezpečnostným silám - východiská a výsledky}

\author{
Jaroslav Kompan, Michal Hrnčiar
}

Abstract: The article discusses the importance of security sector reform. The aim of the article is to present the potential of the concept of security sector reform as a NATO tool for prevention and resolution of internal conflicts on the real example of the deployed military advisory team of the Armed Forces of the Slovak Republic to the ISAF operation in Afghanistan. The authors focus on the orientation in the topic and correlation and causal anchoring of the topic in the introduction and the first part of the article. The second part presents the initial situation of the deployment of the Slovak advisory team in the ISAF operation. The third part and the discussion summarize lessons identified from the deployment of the advisory teams of the Armed Forces of the Slovak Republic. It also illustrates the conceptual framework, conditions and axioms for optimal and effective security force assistance within the efforts of the security sector reform as an important part of the stabilization and reconstruction concept.

Abstrakt: Článok pojednáva o význame reformy bezpečnostného sektora. Ciel'om článku je na reálnom príklade vyslaného príspevku OS SR v podobe vojenského poradenského tímu do operácie ISAF v Afganistane prezentovat' potenciál konceptu reformy bezpečnostného sektora ako nástroja NATO na prevenciu a riešenie vnútroštátnych konfliktov. Autori sa v úvode a v prvej časti článku zameriavajú na základnú orientáciu v problematike, korelačné i kauzálne ukotvenie témy. Druhá čast' predstavuje východiskovú situáciu nasadenia slovenského poradenského tímu do operácie ISAF. Tretia čast' a diskusia sumarizuje identifikované poznatky z nasadenia poradenských tímov OS SR. Tiež znázorňuje koncepčný rámec, podmienky a axiómy pre optimálnu a efektívnu asistenciu bezpečnostným silám $v$ rámci úsilia reformy bezpečnostného sektora ako dôležitej súčasti konceptu stabilizácie a rekonštrukcie.

Keywords: $\quad$ Security Sector Reform; Slovak Security Force Assistance Advisory Team; Afghanistan.

Kl'účové slová: reforma bezpečnostného sektora; Slovenský poradenský tím asistencie bezpečnostným silám; Afganistan. 


\section{INTRODUCTION}

The international community has undergone a major transformation since the end of the Cold War to meet the security and political challenges of the $21^{\text {st }}$ century. Achieving this goal effectively depends on the ability to respond quickly and effectively to a range of scenarios. ${ }^{1}$ Compared to the past, these apply not only to the conventional or irregular conflict but also to the prevention of conflicts by stabilization and reconstruction of the environment degraded by conflict. ${ }^{2}$ Ensuring stability is primarily based on the principle of proactive, respectively immediate deployment of international forces into Crisis response operations abroad. It is caused by globalization and technological progress, because "local" geographically limited areas of tension and instability can cause instability in the wider security environment without a timely solution, ${ }^{\mathbf{3}}$ including the security environment of the Euro-Atlantic area, ${ }^{4}$ or even with an impact on global stability. ${ }^{5}$

The fundamental approach of the international community towards maintaining long-term, ideally permanent security is to prevent the outbreak of violence by permanent presence of stabilizing forces in the crisis area, but also broad support for the social, economic or economic development of conflict-affected communities. ${ }^{6}$ It is the concept of Stabilization and Reconstruction (S\&R) as a tool primarily aimed at alleviating complex problems in fragile states that represents the dominant instrument used by the international community and the Alliance. The main purpose of this concept is to maintain, promote or restore stability in order to create the conditions for long-term sustainable peace.

Stabilization is focused on mitigation of the impact of the crisis and support legitimate political authorities, by those creating the conditions for long-term stability. It requires a comprehensive deployment of both civilian and military capabilities in order to reduce acts of violence, restore security and mitigate or even resolve social, economic and political disagreements. An integral part of the S\&R concept is also reconstruction, which is primarily aimed at rebuilding the physical infrastructure damaged in the conflict and government institutions degenerated by the crisis.

1 MAJCHÚT, Ivan. 2018. Deployability of Armed Forces in Irregular Warfare. In: The Knowledge-Based Organization - Management and Military Sciences. Sibiu: Nicolae Balcescu Land Forces Academy, 2018, pp. 130-136. ISBN 978-973-153-325-4. DOI: 10.1515/kbo-2018-0019.

2 SPILÝ, Peter; HRNČIAR, Michal. 2013. Vojenská taktika. 1. vyd. Liptovský Mikuláš: Akadémia ozbrojených síl gen. M. R. Štefánika, 2013. 272 p. ISBN 978-80-8040-471-0.

3 MAXIM, Milan. 2016. Miesto a úlohy ozbrojených síl pri predchádzaní a riešení konfliktov. In: Národná a medzinárodná bezpečnost' 2016. Liptovský Mikuláš: Akadémia ozbrojených síl gen. M. R. Štefánika, 2016, pp. 17-21. ISBN 978-80-8040-534-2.

4 SPIŠÁK, Ján a kol. 2018. Operační prostředí 2019: Implikace pro použitía rozvoj ozbrojených sil ČR 2019. Brno: Univerzita obrany v Brně, 2019. 18 p. ISBN978-80-7582-341-0.

5 HOFREITER, Ladislav; ŠIMKO, Juraj. 2007. Zdroje a oblasti konfliktov súčasného sveta. Liptovský Mikuláš: Akadémia ozbrojených síl gen. M. R. Štefánika, 2007, 95 p. ISBN 978-80-8040-330-0.

6 HRNČIAR, Michal. 2017. Možnosti zvýšenia efektivnosti operácii proti povstaniu [dissertation thesis]. Liptovský Mikuláš: Akadémia ozbrojených síl gen. M. R. Štefánika, 2017. 
The applicability of this concept is particularly suitable for internal conflicts characterized by a decline in the level of security and stability of the state caused by the consequences of a crisis or conflict. This situation creates a living space for the emergence and development of various opportunistic groups (non-state actors) ${ }^{7}$ and the subsequent promotion of their own interest, often even by irregular activities ${ }^{8}$, in an environment "not governed" by the government. Destabilizing actors have the greatest influence until Host nation (HN) itself is able to ensure its own internal and external security. Therefore, the urgent effort of the international community is to restore the local security sector through Security Sector Reform (SSR). "SSR features prominently in the mandates of United Nations peacekeeping operations, and is increasingly recognized as an essential element in post-conflict peacebuilding."9

The SSR is a cornerstone of other activities in building stable peace. It involves building and development of the capabilities of the HN security forces to independently perform tasks related to ensuring a secure environment in a crisis or conflict-affected state. This platform requires support from international community in the form of training, advice and assistance. SSR is a gradual process and HN's responsibility for its own security is not the result of an immediate change but a gradual increase in the capabilities of the security sector supported by international actors.

SSR should be managed in a complex and systematic manner with main emphasis: ${ }^{10}$

- to recognize and act on linkages between security sector reform and development,

- to be supported as part of a society-wide rather than a State-centric approach,

- to be provided for "South-South" cooperation on security sector reform,

- on promoting transparency, responsibility and participation to ensure the effective and accountable delivery of safety and security.

The SSR should be aimed at restoring or transforming all HN security actors and institutions, including their mission, responsibilities and activities. The ultimate goal is to achieve a state when the $\mathrm{HN}$ government is able to take responsibility for its own security while respecting human rights and laws, without the need for the support of international forces. Achieving this goal requires the expertise and sustainability of HN security forces at all levels of command and control.

7 VARECHA, Jaroslav. 2018. Revolúcia vo vojenských záležitostiach. In: Národná a medzinárodná bezpečnost' 2018. Liptovský Mikuláš: Akadémia ozbrojených síl gen. M. R. Štefánika, 2018, pp. 500-506. ISBN 978-80-8040-568-7.

8 HRNČIAR, Michal. 2017. Keystones of Irregular Warfare. In: The Knowledge-Based Organization Management and Military Sciences. Sibiu: Nicolae Bălcescu Land Forces Academy, Romania, 2017, pp. 150-154. ISBN 978-973-153-273-8. DOI: 10.1515/kbo-2017-0023

9 KI-MOON, Ban. A Word from:Mr. Ban Ki-moon Secretary-General [online]. [cit. 2021-04-01]. In: The United nations SSR prespective. Available at: <https://www.un.org/en/events/peacekeepersday/pdf/ securityreform.pdf>.

10 Identical letters dated 7 February 2013 from the Permanent Representative of Slovakia to the United Nations addressed to the Secretary-General, the President of the General Assembly and the President of the Security Council (A/67/740 S/2013/85) [online]. [cit. 2021-04-01]. Available at: <https://digitallibrary. un.org/record/744706? ln=en>. 
Despite of the fact that NATO SSR efforts are doctrinally based on UN guidelines, UN efforts are more focused to Africa continent. ${ }^{11}$ An example of the Alliance's involvement in resolving the crisis associated with the application of the SSR is e.g. Operation of the International Security Assistance Force (ISAF) in Afghanistan, which also included the Armed Forces of the Slovak Republic (AF SR) contribution represented by the Security Force Assistance Advisory Team (SFAAT). One of the key missions of the Slovak SFAAT in the ISAF operation was to provide advice on the training of a selected Security Force Assistance (SFA) object. This task included the transformation of the doctrinal environment and the systematic education and training of commanders, staffs and units of the Mobile strike forces (MSF) of the Afghan national army (ANA).

The subject of the article is to illustrate the influence of the international community on peace-building and the development of sustainable democratic government of the $\mathrm{HN}$. The aim of the article from "micro-level" perspective is to present the potential of the SFA concept as a tool for resolving emerging internal conflicts on a real example of the deployed contribution of the Armed Forces of the Slovak Republic in the form of SFAAT to the ISAF operation in Afghanistan. The main contribution of the article is a demonstration of the acquired theoretical knowledge and empirical experience of the authors from the deployment within the advisory teams of the Armed Forces of the Slovak Republic in the ISAF operation, namely the illustration of the conceptual framework, conditions, principles and axiom of success of the Security force assistance concept as a part of wider Security sector reform efforts. Because Security sector reform is an essential part of the international community's broad, comprehensive and integrated approach to crisis management.

The article is divided into four parts. The first part is devoted to defining the NATO SSR concept background and its link to the operation ISAF. The second part deals with the overall situation relevant for the deployment of the Slovak SFAAT in Afghanistan. The third part summarizes the knowledge gained by the authors and practical experience from the deployment in the ISAF operation, which are a suitable starting point for creating options to support the reform of the armed forces of the fragile state by relatively small contributions of small armed forces. The discussion presents proposals for axioms of optimal operation and effective deployment of military forces within the SSR with main focus on SFA.

\section{NATO CONCEPT OF SFA AS A PART OF WIDER SSR AND ITS CORRELATION WITH ISAF OPERATION}

The approach to the assessment of the security environment is an extremely sophisticated activity due to its complexity, the dynamics of its changes, instability and the

11 Security sector reform [online]. [cit. 2021-04-01]. Available at: <https://peacekeeping.un.org/en/ security-sector-reform>. 
intertwining of the influences of individual actors. ${ }^{12}, 13$ NATO's contemporary stabilization and reconstruction activities are mainly focused on developing the capabilities of NATO's partner countries. ${ }^{14}$ Through a comprehensive reform of the HN Armed Forces as part of the SSR, these operations enhance and develop security in the Euro-Atlantic area, but also outside it. The S\&R of post-conflict states creates the conditions for the development of international security and stability, acts preventively against the spread of conflicts to other regions and responds effectively to security challenges and threats in the $21^{\text {st }}$ century. ${ }^{15}$

Based on the experience from the SSR, it is visible that the SSR is a catalyst for the democratization of the state and at the same time a suitable tool for converting political decisions into practical support activities. Under the SSR, the military forces are mainly focus in particular on executing the Security Force Assistance, Stability Policing and Disarmament, Demobilization and Reintegration. In general, the SSR will ensure an improvement in the following areas of the security sector: ${ }^{16}$

- Democratization of the state - based on the transformation of security institutions and supervisory and governing bodies to support the development of democracy in a fragile state.

- "Good governance" - resulting from democratic elections in which politicians' representatives of citizens who are transparently elected, can promote the interests of the state and have control over the security sector of the state.

- Economic development - with regard to the security sector, which should have sufficient resources to ensure the external and internal security of the state, but these resources must be used transparently and responsibly.

- Internal and regional conflict prevention - requires effective management of internal tensions and conflicts and providing equal access to justice and security for all citizens of the state.

- Post-conflict reconstruction and recovery - based on the demobilization of combatants from the previous conflict and their reintegration into society and the integration of legitimate armed forces into the newly built security sector.

12 BUČKA, Pavel; PÁSTOR, Rudolf. 2019. Možné prístupy k hodnoteniu bezpečnostného prostredia. In: Národná a medzinárodná bezpečnost' 2019. Liptovský Mikuláš: Akadémia ozbrojených síl gen. M. R. Štefánika, 2019, pp. 96-105. ISBN 978-80-8040-582-3.

13 MUŠINKA, Miroslav. 2020. Možnosti hodnotenia bezpečnostných hrozieb. In: Vojenské reflexie, Vol. XV., No. 1 (2020), pp. 82 - 98. ISSN 1336-9202.

14 KOMPAN, Jaroslav. 2019. Aktuálny doktrinálny rámec operácií NATO na podporu mieru. In: Národná a medzinárodná bezpečnost' 2019. Liptovský Mikuláš: Akadémia ozbrojených síl gen. M. R. Štefánika, 2019, pp. 248-257. ISBN 978-80-8040-582-3.

15 KOMPAN, Jaroslav. 2018. Vonkajšia bezpečnost' Slovenskej republiky v kontexte novej bezpečnostnej stratégie. In: New Approaches to the National Security. Brno: Univerzita obrany v Brně, 2018, pp. 86-91. ISBN 978-80-7582-037-2.

16 KARKOSZKA, Andrzej. 2003. The Concept of Security Sector Reform. [online] 2013. [cit. 2020-12-21] Available at: <https://www.un.org/ruleoflaw/files/Karkoszka.pdf>. 
- Professionalization of security forces - with an emphasis on clearly defined responsibilities and tasks performed by individual security forces and compliance with the law.

Above all, the most important task for ISAF was to ensure the transformation of the Afghan National Security Forces to be able to independently and effectively ensure Afghanistan's external and internal security. Afghanistan after decades of violence ${ }^{\mathbf{1 7}}$ was dependent on international assistance because the state was independently unable to carry out full-fledged reform on its own without international aid. SFA was a key element of the Afghan defence reform, which was aimed at implementing development activities and supporting the sustainable capabilities of local armed forces and their associated institutions. ${ }^{18}$ SFA serves to develop responsible, sustainable, competent and credible security forces that are able to meet the security challenges of Afghanistan.

One of the most fundamental aspects of this assistance to the Afghan national security forces (ANSF) was to develop their ability to be fully responsible for security of Afghanistan. From the first operation of the coalition forces in Afghanistan in 2001 until the termination of the ISAF operation in 2014, the need to meet this expected end state was the priority. However, despite a general understanding of SSR at all levels of NATO command and control, the deployment and operations have not always been optimally planned. ${ }^{19}$

The course of the SSR, in the case of Afghanistan or even more Iraq, documents that if the SSR is affected by contradictory intentions of various regional and global security actors and it is not linked to national specifics of $\mathrm{HN}$, the whole system does not produce the desired end state. ${ }^{20}$ The SSR also possess the risk of uncoordinated intentions of various civilian agencies, which, while developing some part of the security sector, do not synchronize this development with other components. The main sources of SSR failure in a post-conflict state could be the following situations: ${ }^{\mathbf{2 1}}$

- Strong security forces, while democratic principles, civilian oversight and law enforcement are not yet in place in the state, can become a significant destabilizing factor, as power can be usurped by commanders of these forces at local, regional and national levels.

17 HOWK, C. Jason; HYDE, Andrew; PFORZHEIMER, Annie. 2020. Four Lessons for Security Sector Reform in Afghanistan [online] 2013. [cit. 2021-04-01]. Available at: <https://www.usip.org/publications/2020/10/ four-lessons-security-sector-reform-afghanistan>.

18 NATO. 2016. AJP-3.16 Allied Joint Doctrine for Security Force Assistance. Brussels: NSO, 2016.

19 MOERBE, Wesley. 2013. Early Mistakes with Security Forces Advisory Teams in Afghanistan. In: Military Review Journal (May-June). [online] 2013. [cit. 2020-12-21]. Available at: <https://www.armyupress.army. mil/Portals/7/militaryreview/Archives/English/MilitaryReview_20130630_art007.pdf>.

20 KOMPAN, Jaroslav. 2018. Koncepčný rámec nasadenia slovenského poradenského tímu v operácii ISAF Afganistan v roku 2014. In: Národná a medzinárodná bezpečnost' 2018. Liptovský Mikuláš: Akadémia ozbrojených síl gen. M. R. Štefánika, 2018, pp. 173-178. ISBN 978-80-8040-568-7.

21 SEDRA, Mark. 2007. Security Sector Reform in Afghanistan and Iraq: exposing a concept in crisis. In: Journal of Peacebuilding and Development, Vol. 3., No. 2(2007), pp.7-23. Available at: <https://gsdrc.org/ document-library/security-sector-reform-in-afghanistan-and-iraq-exposing-a-concept-in-crisis/>. 
- Implementation of short-term solutions at the expense of the long-term development of democratic and accountable security forces and judicial institutions, such as the provision of equipment without an education and training system.

- Focusing on addressing the consequences of conflict instead of developing long-term mechanisms to address the root causes of conflict.

- The late establishment of a judicial system, where law enforcement agencies detain perpetrators of illegal acts but there is no fair and independent judiciary to sanction them.

- Usurpation of the SSR by only one actor who promotes his own security interests through the SSR, regardless to the needs of HN.

\section{SLOVAK SECURITY FORCE ASSISTANCE ADVISORY TEAM -} OVERALL SITUATION AND INPUTS TO THE DEPLOYMENT

ISAF coalition forces have been deployed in Afghanistan since December 2001 to assist Government of the Islamic republic of Afghanistan (GIRoA) in maintaining a security environment in and around Kabul. ${ }^{22}$ NATO took the lead over ISAF operation in Afghanistan, on $11^{\text {th }}$ August 2003. The United nations Security council (UN SC), by Resolution no. 1510, extended ISAF's mandate to the whole of Afghanistan, on $13^{\text {th }}$ October 2004.

The Alliance agreed to shift to the 4th phase "TRANSITION" of the ISAF operation, with the aim of gradually transfer responsibility for Afghanistan's security and governance to its military and security authorities at the NATO Summit in Lisbon, in November 2010. ANSF began to take the lead in security operations in almost all regions of Afghanistan, at the end of 2011 and the beginning of 2012. The main intent of this effort was to allow the withdrawal of ISAF units from the Afghanistan by the end of $2014 .{ }^{23}$ To achieve this goal, ISAF introduced the concept of SFA. ${ }^{24}$

SFA concept for ISAF operation was approved by the ISAF Commander in late 2011 and also approved by NATO in early 2012. SFA was primary tool in the ISAF operation's "TRANSITION" phase and an element that ensured the successful transfer of authority to ANSF until the end of 2014. Because the Alliance approved a declaration on the termination of the ISAF operation by $31^{\text {st }}$ December 2014 and on the continuation of the NATO-Afghanistan partnership beyond 2014, at the NATO summit, in May 2012. The SFA concept was implemented mainly in the form of advisory during the basic training and reconciliation of local units and then as part of their preparation for the independent execution of operations, in 2012-2014.

22 ISAF's mission in Afghanistan (2001-2014). [online] 2015. [cit. 2021-01-21]. Available at: <https://www. nato.int/cps/en/natohq/topics_69366.htm>.

23ISAF Joint Command (IJC). Operations Plan 1391, Annex F - Security Force Assistance, 10 April 2012.

24 KELLY, Terrence; BENSAHEL, Nora; OLIKER, Olga. 2011. Security Force Assistance in Afghanistan: Identifying Lessons for Future Efforts. Santa Monica: RAND Corporation, 2011. ISBN 978-08-3305-211-7. [online]. [cit. 2021-04-01]. Available at: <https://www.rand.org/pubs/monographs/MG1066.html>. 
The SFA concept has become a method used by coalition forces in Afghanistan to support the fulfilment of their operational tasks in partnership with the ANSF. This concept included multiple activities, in particular, the Organize, Train, Equip, Rebuild - build, and Advise and assist (OTERA), thus increasing the operational efficiency of the ANSF. For NATO, this meant reducing the number of coalition forces deployed in Afghanistan, but on the other hand increasing the contribution to assistance to HN security forces.

Despite all efforts, insurgent structures in Afghanistan have still not been completely curtailed. The basic premise that applies to the implementation of the SFA concept in Afghanistan was that the ANSFs have and have been carrying out, in particular, counterinsurgency (COIN) operations. This means that the whole focus of the SFA concept must be on supporting the ANSF's capacity and capabilities to conduct COIN operations, while reducing the risks arising from the operating environment.

However, this requires a thorough understanding of the specifics of COIN operations in all areas (planning, sustainability, intelligence, etc. $)^{25}$ and a consistent transfer of this understanding to the $\mathrm{HN}$ unit. The actual execution of operations took place without the intervention of advisors, which ensured an increase in the credibility of the ANSF, especially for the local population. ${ }^{26}$

The Armed Forces of the Slovak Republic have been actively involved in the ISAF operation on the basis of a resolution of the National Council of the Slovak Republic (NC SR), since June 2004. As a consequence of NATO summit in Lisbon, in November 2010, Slovak Republic demonstrated its eminent interest on the transformation of the ANSF and this interest was confirmed by deployment of the SFAAT, in 2014. The NC SR, by its resolution no. 113 approved the deployment of the SFAAT to support the critical priority of the ISAF operation. ${ }^{27}$

The decisive task of Slovak SFAAT was to provide assistance to the Afghan National Army (ANA) mobile strike force. This required support to ANA units, comprehensive advisory in several provinces with the ability to be deployed throughout Afghanistan. But there also had to be a change of mindset and the abandonment of the mentoring system, which required the continued presence of mentors within Afghan troops. Rather, the concept of advisory focused on supporting already trained HN security forces and developing their combat potential by providing advisory, assistance, training, and systemic development of critical capabilities. ${ }^{28}$ The advisory was normally executed at the three levels (1-2-3) and Slovak SFAAT was tasked to execute all of them:29

25 HRNČIAR, Michal. 2018. The Counter Insurgency Operating Environment. In: The Knowledge-Based Organization - Management and Military Sciences. Sibiu: Nicolae Bălcescu Land Forces Academy, 2018, pp. 87-92. ISBN 978-973-153-325-4. DOI: 10.1515/kbo-2018-0013

26KOMPAN, Ref. 20.

27 Uznesenie Národnej rady Slovenskej republiky č. 113/2013 k návrhu na vyslanie, predľ́zenie času vyslania a ukončenie času vyslania príslušníkov ozbrojených síl Slovenskej republiky vo vojenskej operácii ISAF. Bratislava: NR SR, 2013.

28Report on Enhancing Security and Stability in Afghanistan. Washington: Department of Defense, 2015.

29 Afghan War News. Security Force Assistance (SFA) in Afghanistan. [online] 2014. [cit. 2021-01-21]. Available at: <http://www.afghanwarnews.info/sfa/afghanistansfa.htm>. 
- Level 1 - the highest level of advisory. The advisory unit performs advisory of the HN unit on a daily basis. The SFAAT is located on the same base (or a very close coalition base) and is ready to respond immediately to the demands of the domestic unit, including the execution of combined operations.

- Level 2 - The advisory unit cooperates with the domestic eligible unit and monitors only compliance with the standards and the development of competencies set by the ANSF command. SFAAT may also carry out such activities for the benefit of several domestic units, as daily supervision is not required.

- Level 3 - the least effective form of advisory. Contact with the home unit is carried out by advisors only by telecommunication means, physical visits are limited to the organization of joint conferences, where the $\mathrm{HN}$ units independently document the level of their development.

The key factors that influenced the optimal performance of advisory mission were extreme security situation and demanding weather and terrain conditions. The security situation in Afghanistan was extreme, in 2014. Insurgent attacks were carried out at the military bases of coalition and $\mathrm{HN}$ security forces, as well as at units executing mission outside the bases. Very demanding issue were incidents of insurgent infiltration into coalition bases and attacks at coalition forces by members of the ANSF (so called "Green on Blue attacks"). These incidents were very common due to the inadequate attitude of coalition forces to the ANSF, as well as the insurgents' ongoing ability to infiltrate the ANSF. Non-kinetic activities of the insurgents were aimed at intimidating the local population and an information campaign. ${ }^{30}$

Another significant factor was that the SFA object - military unit was a newly created unit. It was established in the second half of 2013. This meant that it was still in the phase of full mentoring and at the beginning of SFAAT's activities it was still without combat and operational experience. Commanders were moved from another ANA units and have no knowledge of newly built ANA doctrinal system, soldiers newly recruited. ${ }^{\mathbf{3 1}}$

All the above-mentioned factors significantly influenced the deployment. In particular, the extreme security situation significantly "tied the hands" of advisors in the implementation of the established SFA concept.

30 KOMPAN, Ref. 20.

31 KOMPAN, Jaroslav. 2018. Výcvik manévrového úderného práporu Afganskej národnej armády slovenským poradenským tímom v operácii ISAF Afganistan v roku 2014. In: Národná a medzinárodná bezpečnost' 2018. Liptovský Mikuláš: Akadémia ozbrojených síl gen. M. R. Štefánika, 2018, pp. 179-184. ISBN 978-80-8040-568-7. 


\section{SLOVAK SECURITY FORCE ASSISTANCE ADVISORY TEAM - LESSON IDENTIFIED FROM DEPLOYMENT}

\subsection{SFA object must be suitable and perspective for long-term development}

SFA object training and advising itself must directly support the competencies that guarantee the vigorous suppression of hostile activities, but also enhance the natural confidence of the local population (as part of the "Minds and Hearts" approach). ${ }^{32}$ It is therefore necessary to focus advice in particular on rapid decision-making, leaders integrity and, in addition, as consequence of the security situation, on developing the ability to perform dynamic maneuvers and ensure combat projection throughout the area of operations with an emphasis on maintaining a high tempo, survivability on the battlefield with extreme occurrence of explosive threats. Of course, a crucial element is also the development of the skills to sustain the operations, especially in a way of logistic support and equipment care. Without those, unit combat readiness is limited. ${ }^{33}$

When selecting a suitable SFA object, it is advisable to perform a thorough analysis, which results in a correctly identified SFA object. The analysis must include, in particular, an assessment of the future impact of a particular military component or subsystem on the overall security in a specific region or area or for larger components throughout the country. ${ }^{34}$ Mobile strike forces are preferable due to their capability of conducting security operations over a larger geographical area. Additionally, there is higher probability of better equipment which will allow better capability projection and more flexible continuous interaction with the population. ${ }^{35}$ At the same time, it is likely that the leaders and also units' members will meet higher personnel standards in comparison with other units and this creates conditions for long-term and sustainable development. ${ }^{36}$ The longitudinal issue is that SFA providers and their HN counterparts should plan a long-term transition to sustainable force. Specifically, when the insurgency presents long-term challenge as in Afghanistan. ${ }^{37}$

32 TURAJ, Milan. 2018. Zhodnotenie aktuálneho stavu bojového použitia predsunutých leteckých navádzačov v podmienkach Ozbrojených síl Slovenskej republiky. In: Vojenské reflexive. Vol. XIII., No. 2 (2018), pp. 164 -174. ISSN 1336-9202.

33 KOMPAN, Ref. 31.

34 KOMPAN, Jaroslav. 2019. Using the SWOT analysis of the external security of the Slovak republic as a basis for defense planning. In: Security Forum 2019. Banská Bystrica: Univerzita Mateja Bela, Interpolis, 2019, pp. 59-66. ISBN 978-80-973394-1-8.

35 Afghan War News. ANA Mobile Strike Force (MSF). [online] 2013. [cit. 2021-01-21]. Available at: <http:// www.afghanwarnews.info/army/mobilestrikeforce-msf.htm>.

36 Report on Enhancing Security and Stability in Afghanistan. Ref. 28.

37 KELLY et al., Ref. 24. 


\subsection{SFA object has its own priorities but those needs to be assessed for compliance with HN standards}

"There was a very real threat the army would not be able to adapt fast enough in capability and size to stop the nation from returning to a civil war. This echoes some of today's concerns, especially if spoilers and splinter groups work to stop peace from fully taking hold." 38 The task of the advisors was to carry out continuous assessment of the SFA object capability development, which ensured that the SFA object's training met ANA standards and resources were used effectively. The most fundamental deficiencies were assessed mainly in the capabilities of individuals, units' tactics, and decision-making to execute and sustain the operations in the area of operations contaminated with explosive threats. This deficiency influenced evaluation in most other areas. ANA General Staff identified this deficiency as crucial capability to be developed by advisors in the mission-essential tasks list. At the same time, given the ANA's casualties statistics, improving the SFA object's capabilities to reduce the impact of explosive threats also increased the ability to protect forces and survive on the battlefield. The toughest challenge, then, was to harmonize the activities of all subordinate components of the SFA object so that as a whole it would achieve full operational readiness - Full operational capability (FOC) within the timeline set by the superior headquarters of ANA. These areas were critical to achieving the capabilities that were designed and expected from all SFA objects and fully followed the expected final state of the "TRANSITION" phase of the ISAF operation. ${ }^{39}$

A critical element of advising efforts was also to support the SFA object's relations with local authorities and the civilian population so that it was identified as a natural, responsible and proactive "protector" of the civilian population against insurgent activities. This comprehensive activity therefore required advisors to support the development of the SFA object and to be as present and visible as possible during training and operations, but not to take the initiative so that Afghan commanders come to the fore. ${ }^{40}$

Furthermore, advisors should understand not only how to deploy own national and coalition forces but also how to develop HN forces and employ them with coalition forces in such a way that both $\mathrm{HN}$ and national interests are met. ${ }^{41}$

The training was carried out not only at the bases, but combined operations with coalition partners from NATO were also identified as advantageous training conditions, where the SFA object firstly performed supporting tasks and gradually took the initiative in order to be self-sufficient force. ${ }^{42}$

38 HOWK et al., Ref. 17.

39 KOMPAN, Ref. 31.

40 KOMPAN, Ref. 31.

41 KELLY et al., Ref. 24.

42 SEDRA, Mark. 2014. An Uncertain Future for Afghanistan's Security Sector. In: Stability: International Journal of Security and Development, 3(1), p. Art. 35, pp. 1-16. DOI: http://doi.org/10.5334/sta.ei 
The advisory activities of the Slovak SFAAT thus fully developed the set areas so that the SFA object would be able to independently manage and develop these capabilities before the set deadline for achieving the FOC. Of course, the whole training concept had to support ANA's strategic training concept, the main motto of which is "Train the way you fight!". 43

\section{DISCUSSION}

The Slovak SFAAT managed to achieve a fully capable evaluation with the SFA object in a comprehensive area through comprehensive training and the use of training opportunities. At the same time, the SFA object became completely independent and self-sufficient in the planning of training and subsequent deployment in military operations. Due to the end state projected by the ANA General Staff, the SFA object was able to maintain its capabilities independently, thus confirming its readiness to conduct independent operations without the participation of advisors and taking responsibility for security in a selected region of Afghanistan. ${ }^{44}$ Simplified conceptual model of generic SFA efforts is visible on the Figure 1.

\begin{tabular}{|c|c|c|c|c|c|c|}
\hline $\begin{array}{l}\text { Unit } \\
\text { establishment } \\
\text { Handover of } \\
\text { the equipment } \\
\text { and weaponry }\end{array}$ & $\begin{array}{l}\text { Basic combat } \\
\text { drills } \\
\text { Training centre }\end{array}$ & $\begin{array}{c}\begin{array}{c}\text { Tactical } \\
\text { training }\end{array} \\
\text { Training centre }\end{array}$ & $\begin{array}{c}\begin{array}{c}\text { Progress } \\
\text { assessment }\end{array} \\
\begin{array}{c}\text { Training } \\
\text { centre }\end{array}\end{array}$ & $\begin{array}{c}\text { Operational } \\
\text { training } \\
\text { Area of } \\
\text { operations - } \\
\text { District of } \\
\text { Afghanistan }\end{array}$ & $\begin{array}{c}\text { Taking } \\
\text { responsibility } \\
\text { Area of } \\
\text { operations - } \\
\text { District of } \\
\text { Afghanistan }\end{array}$ & $\begin{array}{l}\text { Ability to } \\
\text { lead SFA for } \\
\text { own HN } \\
\text { units }\end{array}$ \\
\hline 9 weeks & Full mentorin & $\begin{array}{c}21 \\
\text { weeks }\end{array}$ & & $\begin{array}{l}\text { via SFAAT } \\
\begin{array}{c}3-9 \\
\text { months }\end{array}\end{array}$ & $\begin{array}{l}\text { Independently } \\
\begin{array}{l}12-24 \\
\text { months }\end{array}\end{array}$ & ??? years \\
\hline
\end{tabular}

Figure 1: Implementation of SFA into the life cycle of the HN military unit

Given the experience of deployment of the Slovak SFAAT in the ISAF Afghanistan operation, it could be claimed that any effort focused on development of the capabilities of $\mathrm{HN}$ units requires compliance with certain standards. Due to their universal validity, these standards could be called axioms of effective SFA and are based on 15 principles of SFA valid for operation ISAF Afganistan: ${ }^{45}$

(1) One SFA object requires one SFAAT - in order to maintain a continuum in advisory, but also to establish relationships that ensure mutual understanding and comprehension.

43 Afghan National Army Field Manual ANA 0-3.1. Train the Force. Kabul. 2013.

44 KOMPAN, Ref. 31.

45 ALLEN, John. 2012. 15 principles of SFA [online]. [cit. 2021-04-01]. Available at: <https://afghanwarnews. info/sfa/15principlesofsfa.htm>. 
(2) SFA is not just a task for SFAAT - it is performed by all units coming into contact with HN units.

(3) When advising to the SFA object, implement such training methods that will be not only acceptable but also successful. ${ }^{46}$

(4) The SFA object may fail - therefore it is necessary to set the right indicators that can identify negative impacts in time.

(5) The SFA object should be visible - especially with regard to the interaction with the local population, which should perceive the SFA object as a guarantor of security. Therefore, it is better for the HN unit to do something "good enough" than for the coalition unit to do it perfectly.

(6) Requirements and tasks from the HN headquarters have priority - because the SFA object is not established as a coalition unit, but as part of the HN security forces, which have the right to use it in accordance with their own directives.

(7) Understand the cultural specifics of a particular area - understand that SFAs are performed in a fragile state and cultural differences cannot divide or bring about conflicts.

(8) SFA must be a constantly flexible response tool - responsive to the needs of HN and the development of the $\mathrm{HN}$ security environment.

It follows from the above that by application and constant and thorough evaluation of the above axioms it is possible to achieve the overall success of the SFA, and thus support the overall success of SSR and its projected target state, i.e. stability, consistently and long-term sustainable peace in a fragile state.

\section{CONCLUSION}

None of the major international peacekeeping operations or peacekeeping missions has yet achieved the required political goal of transforming the target $\mathrm{HN}$ into a stable, independent and prosperous liberal democracy. ${ }^{47}$ One such example is the Afghanistan where the internationally supported stabilisation and state-building efforts have not been a success. ${ }^{48}$ But this was relevant initially before the operation ISAF has made a significant contribution to the effective transformation of the ANSF, with its SFA concept.

The security policy of the Slovak Republic is guided not only by narrowly defined territorial interests, but also by the principles of solidarity with the Allies. The Slovak Republic has the potential to participate in the efforts of the international community

46 ZAHRADNÍČEK, Pavel; RAK, Luděk. 2020. Modern Teaching Methods Implemented in Training of Students of University of Defence. In: International Journal of Latest Research in Science and Technology, Vol. 9, Issue 2 (2020), pp. 13-17. ISSN 2278-5299.

47 DOPITA, Tomáš. 2011. Liberální vládnutí buduje liberální mír. Armádní a policejní reforma v Bosně a Hercegovině. In: Mezinárodní vztahy, Vol. 46, No. 2 (2011), pp. 35-56. ISSN 2570-9429 (Online).

48 AYUB, Fatima; KUOVO, Sari; WAREHAM, Rachel. 2009. Security sector reform in Afghanistan - Country case study: Afghanistan. Brussels: IFP Security Cluster, 2009. [online]. [cit. 2021-04-01]. Available at: <https://www.ictj.org/sites/default/files/ICTJ-Afghanistan-Security-Reform-2009-English.pdf>. 
in managing and resolving crisis situations. These efforts may include prevention, the deployment of military and civilian assets to address or to solve the consequences of conflicts and crises, as well as stabilization efforts, reconstruction and subsequent sustainable development. For this purpose, the Armed Forces of the Slovak Republic must be able to carry out specific activities to achieve the objectives in accordance with the strategic ambitions of the Slovak Republic. ${ }^{49}$

If the Slovak Republic wants to promote its security interests, it should address not only local or regional security threats or challenges but it must also support development of the fragile states security sector as a prevention. ${ }^{50}$ The ambition of the Slovak Republic to deploy SFAAT to the ISAF operation in 2014 resulted from the shift of the ISAF operation to the "TRANSITION" Phase and it contributes to the success of wider Alliance SSR efforts in Afghanistan. The Armed Forces of the Slovak Republic have clearly demonstrated their ability to contribute to the development of the ANSF and that they are a valuable coalition partner for the rest of the Alliance.

The deployment of SFAAT brought many lessons identified for the Armed Forces of the Slovak Republic and many of them were applied to training or to normative documents. All of these lessons could simplify the preparation for other similar deployment in the future. For example, in this case lessons identified served as a basis for the preparation of advisory teams for the NATO Training Mission in Iraq (NTM-I).

At the same time, however, it should be assumed that regardless of the country of deployment it is always necessary to select SFAAT members very carefully. The reason is the high risk of endangering the lives of members of the Armed Forces of the Slovak Republic and the need to manage cultural, religious, ethnic and geographical specifics ${ }^{51}$ to minimize so called "GREEN on BLUE" incidents. 52

Authors: $\quad$ Major Jaroslav Kompan, was born 1982. He graduated the Faculty of Land Forces of the Armed Forces Academy in Liptovský Mikuláš in 2005. He is external doctoral student of the Department of Security and Defence, specialization Defence and Military. He works as an assistant at Military Tactics and Operational Art Department at the Armed Forces Academy of General M. R. Štefánik in Liptovský Mikuláš. He has been assigned as a military advisor to various Afghan National Army combat units. He specializes in field of research of international security, operational art, military engineering. He is author of wide portfolio of scientific and professional articles in domestic and foreign journals.

49 ANDRASSY, Vladimír. 2019. Slovenská republika v operáciách NATO po summite vo Varšave. In: Politické vedy, Vol. 22, Issue 1 (2019), pp. 80-107. ISSN 1335-2741, ISSN 1338-5623.

50 KOMPAN, Ref. 15.

51 HRNČIAR, Ref. 25.

52 KOMPAN, Ref. 20. 
Major Michal Hrnčiar, PhD, was born 1980. He graduated the Faculty of Land Forces of the Military Academy in Liptovský Mikulás in 2004. He completed his doctoral studies at the Academy of the Armed Forces of General M. R. Štefánik, specialization National and International Security, in 2017. He works as an assistant professor at Military Tactics and Operational Art Department at the Armed Forces Academy of General M. R. Štefánik in Liptovský Mikuláš. He has been deployed twice to UNFICYP. He specializes in field of research of military arts and security. He is co-author of a textbook, a monography and the wide portfolio of scientific and professional articles and studies in domestic and foreign journals.

How to cite:KOMPAN, Jaroslav and Michal HRNČIAR. Security force assistance advisory team - inputs and outcomes. Vojenské rozhledy. 2021, 30 (2), 055-069. ISSN 1210-3292 (print), 2336-2995 (online). Available at: www.vojenskerozhledy.cz 